Polat, ì. ve Dedeoğlu, H. (2020). Sınıf öğretmenlerinin hazırladığı metin altı sorularının incelenmesi. Ana Dili Eğitimi Dergisi, 8(4), 1468-1482.

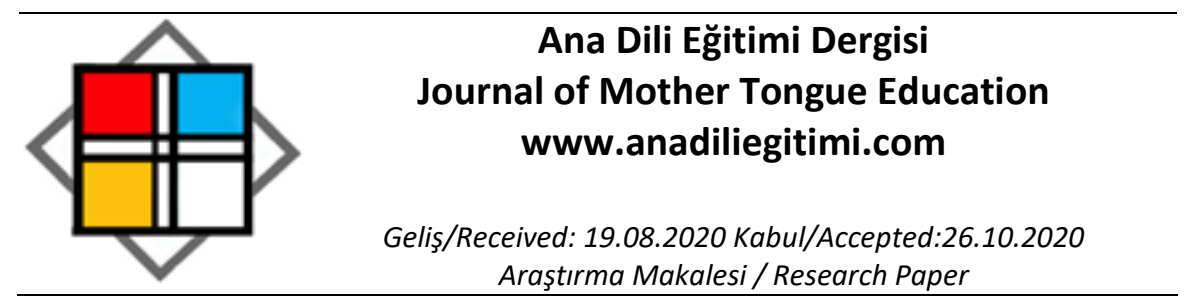

\title{
Sınıf Öğretmenlerinin Hazırladığı Metin Altı Sorularının İncelenmesi
}

\author{
IIhan POLAT \\ Hakan DEDEOĞLU**
}

\begin{abstract}
Öz
Bu çalışmanın amacı, sınıf öğretmenlerinin okuduğunu anlamaya yönelik hazırladığı metin altı sorularının çeşitli yönlerden incelenmesidir. Çalışma, nitel araştırma yönteminde bütüncül tek durum desenli bir durum araştırması olarak tasarlanmıştır Veriler, doküman incelemesi yöntemiyle www.egitimhane.com ve www.sinifogretmeniyiz.biz adlı internet sitelerinden 4. sınıflara yönelik okuduğunu anlama çalışmaları ve Türkçe yazılı sınavlarından alınan metinler ile bu metinlere yönelik metin altı sorularından elde edilmiştir. Verilerin analizinde betimsel analiz yöntemi kullanılmıştır. Metin türleri için hikâye edici, bilgilendirici ve şiir türü sınıflandırılma esas alınmıştır. Soruların cevap kaynaklarına göre analizinde cevabı metin içi, metin dışı ve metinler arasında olan sorular şeklindeki sınıflama esas alınmıştır. Soru düzeylerinin sınıflandırılması Barrett Taksonomisi'ne göre yapılmıştır. Çalışmadan elde edilen bulgulara göre öğretmenlerin okuduğunu anlamaya değerlendirmek için en fazla hikâye edici metinleri kullandığı, büyük oranda kısa cevaplı ve çoktan seçmeli soruları tercih ettiği, cevap kaynağııı tamamına yakınının metin içinde olduğu ve büyük oranda basit anlama düzeyindeki sorular sorduğu sonucuna ulaşılmıştır. Elde edilen sonuçlar bağlamında araştırmacılar ve uygulayııılar için bir takım öneriler sunulmuştur.
\end{abstract}

Anahtar kelimeler: okuduğunu anlama, metin altı soruları, Barrett Taksonomisi

\section{Investigation of text-based reading comprehension questions prepared by primary school teachers}

\section{Abstract}

The present study aimed to investigate text-based reading comprehension questions prepared by primary school teachers. This study was designed as a case study, which is one of the qualitative research methods. The data were collected using the document analysis method. The data were collected from the websites at www.egitimhane.com and www.sinifogretmeniyiz.biz . The data were comprised of reading comprehension activities prepared for 4th-grade students and texts taken from Turkish written exams. The data consisted of texts and text-based questions.A descriptive analysis method was used for data analysis. The data were analyzed according to the text type, question type, answer source and the question level of Barrett's Taxonomy. According to the findings of the research, teachers use narrative texts to evaluate their reading comprehension, and they prefer simple level questions with short answers and multiple choice as questions, the source of the answer is in the text. According to the results obtained, some suggestions are presented for researchers and practitioners.

Keywords: reading comprehension, text-based reading comprehension questions, Barrett's Taxonomy

\footnotetext{
* Doktora öğrencisi, Hacettepe Üniversitesi Eğitim Bilimleri Enstitüsü, İlköğretim Bölümü, ilhan_polatt@ hotmail.com, ORCID: 0000-0002-7802-6337

** Doç. Dr., Hacettepe Üniversitesi Eğitim Fakültesi, Temel Eğitim Bölümü, dede@hacettepe.edu.tr, ORCID: 0000-0003-2436-7010
} 


\section{Giriş}

Bilim ve teknolojinin hızla geliştiği bir dünyada yaşamak, gelişmeleri izlemek ve geleceğe yön vermek için bireylerin bazı becerilerini geliştirmesi gerekmektedir. Bunların başında dil ve zihinsel beceriler gelmektedir (Güneş, 2009). Insanların en önemli iletişim aracı olan dil, anlama ve anlatım üzerine kurulu dört temel beceriden ve bu becerilerin alt boyutlarından oluşmaktadır. Temel dil becerileri; dinleme, konuşma, okuma ve yazma olarak ifade edilmektedir (Göçer ve Şentürk, 2019). Anne karnında başlayan dil edinimi, her ne kadar okul öncesi eğitiminde formal bir sürece evrilse de ülkemizde tam anlamıyla ilkokulda hayata geçmektedir. İlkokulda başlayan dil eğitimi ileriki basamaklarda genişleyerek devam etmekte ve nihayetinde hayat boyu devam etmektedir. Dil eğitiminin amacı, kişiye; okuma, yazma, konuşma ve dinleme adı verilen dört temel dil becerisini kazandırmaktır (Koçak, 2005). Bu anlamda Türkçe dersi programının da bu dört beceri ve buna bağlı alt beceriler üzerine inşa edildiği görülmektedir. Milli Eğitim Bakanlığı 1-8 Sınıflar Türkçe Dersi Öğretim Programı, dil becerilerini ve programdaki yerini şöyle ifade etmektedir:

"Ögrrencilerin hayat boyu kullanabilecekleri dinleme/izleme, konuşma, okuma ve yazma ile ilgili dil becerilerini ve zihinsel becerileri kazanmaları, bu becerileri kullanarak kendilerini bireysel ve sosyal yönden geliştirmeleri, etkili iletişim kurmaları, Türkçe sevgisiyle, istek duyarak okuma ve yazma alışkanlığı edinmelerini sağlayacak şekilde bilgi, beceri ve değerleri içeren bir bütünlük içinde yapılandırılmıştır (MEB, 2019).

Dil becerilerinin edinmesinin, iletişim ve sosyalleşme için önemine vurgu yapılan programda dil becerilerinin önemi şöyle ifade edilmektedir: "Türkçe Öğretim Programı, diğer tüm alanlarda öğrenme, kişisel ve sosyal gelişme ile mesleki becerileri edinmenin ön şartı olarak kabul etmektedir" (MEB, 2019). Temel dil becerilerinden okuma, "ön bilgilerin kullanıldığı, yazar ve okuyucu arasında etkili iletişime dayalı, uygun bir yöntem ve amaç doğrultusunda, düzenli bir ortamda gerçekleştirilen anlam kurma süreci" olarak tanımlanmaktadır (Akyol, 2018). Okumada amaç anlamaktır, yani anlam kurmaktır (Akyol, 2001; Akyol 2003). Okumayla bireyden, metin üzerinde doğrudan veya dolaylı olarak anlam çıkarması beklenir. Bu nedenle okuduğunu anlama, sadece akademik bilgileri öğrenmek için değil, aynı zamanda yaşam boyu öğrenme için gerekli olan bir araç olarak da tanımlanabilir (Ateş ve Yıldırım, 2014). Anlama becerilerinden olan okuduğunu anlama becerisini, ana dili öğretiminin en önemli amaçlarından biri olarak tanımlayan Temizkan ve Sallabaş (2011), anlamanın yazılı ve basılı işaretlerin temsil ettiği anlamın kavranmasıyla mümkün olacağını ifade etmektedir.

Okuduğunu anlama sürecinin en iyi şekilde öğrencilere yansıtılması için öğretmenlerden bir takım çalışmalar beklenmektedir. Block ve Pressley (2007'den aktaran Ateş ve Yıldırım, 2014) bu çalışmaları şöyle ifade etmektedir:

- Öğrencilere farklı metinler üzerinden deneyimler sağlanmalı.

- Bağımsız okuma çalışmalarında öğrencilerin okuma öncesi, okuma sırası ve okuma sonrasında metinlere ilişkin düşünceleri almalı.

- Öğrencilerin okuma amacı oluşturması sağlanmalı.

- Okumadan elde edilen bilginin kullanılması sağlanmalı.

- Metinlerden çıkarımlarda, yargılamalarda ve çözümlemelerde bulunmaları için öğrenciler cesaretlendirmeli.

- Öğrencilere kelimelerin gerçek anlamları öğretilmeli.

- Öğrencilerin ilgili kavramları görselleştirmeleri sağlanmalı.

- Kelimelerin farklı anlamları verilmeli.

- Metinlerle ilişkili görselleri yorumlamaları istenmeli.

- Öğrencilerin edindikleri bilgilerin kültürel çevreleriyle nasıl ilişkilendirecekleri konusunda yardımcı olmalı.

Bireyin okuduğunu anlama düzeyini belirlemek için çeşitli yöntemler kullanılmaktadır. Bu yöntemler arasında en eski ve en sık kullanılan yöntemlerden biri okunan materyalle ilgili öğrenciye soru sormaktır. Okuma sürecinde yazar ile okuyucu arasında etkileşim sağlamanın okuduğunu anlama üzerinde önemine vurgu yapılmaktadır. Bu noktada okuduğunu anlamaya yönelik sorular önemlidir. Çünkü iyi bir etkileşim süreci sağlamak ve anlam kurmak için öğretmenlerin kullandığı en önemli 
araçlardan biri okuduğunu anlamaya yönelik sorulardır (Day ve Park, 2005; Akyol, Yıldırım, Ateş ve Çetinkaya, 2013). Sorular aracılığıyla okuduğu anlama becerisi ölçülerek öğretmene ve öğrenciye değerlendirme imkânı sağlanırken aynı zamanda okuyucu ile yazar arasında bir etkileşim kurularak metnin anlaşılması sağlanır. Okuyucu, okuduğunu anlamaya yönelik iyi hazırlanmış sorular üzerinden metin ile ve dolaylı olarak yazarla etkileşim kurar ve bu sayede anlam kurar. Sorular; öğrencilerin okumaya odaklanmasını, metnin derinliklerine inerek anlam kurmasını ve okuduğunu eleştirel bir şekilde yansıtmasını sağlar (Hervey, 2006).

Okuduğunu anlama sürecinde önemli rolü olan soruların kullanım amacını Akyol (2001), merak uyandırmak, dikkat çekmek, öğrenciyi etkin hale getirmek, öğrenciyi kendine veya başkasına soru sormaya teşvik etmek, öğrenme güçlüklerini tespit etmek, kendini ifade etmeye fırsat vermek, tartışmalar yoluyla öğrenmeyi sağlamak, dersi takip etmesini sağlamak ve ödüllendirmeye dayanak oluşturmak şeklinde ifade etmektedir.

Okuma becerisinin gelişiminin en önemli dönemlerinden olan ilkokulda sınıf öğretmenleri özellikle Türkçe derslerinde okuma ve okuduğunu anlama becerisinin geliştirilmesi için okuduğunu anlamaya yönelik metin altı sorulara sıklıkla başvurmaktadır. Sınıf öğretmenleri hem eğitim materyallerinde hem de kendi hazırladıkları çalışma kâğıdı, yazıı sınavlar ve sınıf içi değerlendirmelerde metin altı soruları kullanmaktadır. Öğretmenlerin anlamaya dönük bu sorularının metnin anlaşılması, okuduğunu anlama becerisinin gelişmesi ve öğrencilerin ileriki öğrenim hayatı için de önemli olduğu bir gerçektir. Çünkü ilkokulda öğrencinin edindiği okuduğunu anlama becerisi, tüm öğrenim hayatının ve diğer derslerdeki başarısının da temelini oluşturacaktır. Çünkü okuma metinlerinin analiz, değerlendirme ve sentez boyutu gibi üst düzeyde anlaşılması Türkçe dersi ile birlikte matematik, fen ve sosyal bilgiler alanı için de önemlidir (Dolapçığlu, 2020).

Alanyazında Bloom (1956), Sanders (1966), Wallen (1972), Pearson ve Johnson (1978), Day ve Park (2005) tarafından geliştirilen çeşitli kategoriler veya taksonomiler olduğu görülmektedir (Çeliktürk-Sezgin ve Gedikoğlu-Özilhan, 2019). Bu taksonomilerden biri de Barrett Taksonomisi'dir. Barrett'e göre öğretmenler, okuduğunu anlama sürecinde iki konuda yanılmaktadır. Bunlardan birincisi, anlamanın tek bir beceri olarak kabul edilmesi, diğeri ise okuduğunu anlamanın yönetilemez ve kontrol edilemez birçok ayrı beceriyi kapsadığını varsaymalardır. Barrett bu sorunu çözmek adına Bloom (1956), Sanders (1966), Letton (1958) ve Guszak'ın (1965) çalışmalarından faydalanarak “Okuduğunu Anlamanın Bilişsel ve Duyuşsal Taksonomisi'ni geliştirmiştir (Yıldırım, 2012). Bu şekilde beş farklı kategoriden oluşan, anlaşılır ve kontrol edilir bir taksonomi meydana gelmiştir. Barrett Taksonomisi, bilişsel ve duyuşsal olmak üzere iki boyutu kapsamaktadır. Taksonominin kategorileri; basit anlama, yeniden organize etme, derinlemesine anlama(çıkarımsal anlama), değerlendirme ve memnuniyet şeklindedir (Akyol vd. 2013). Her ne kadar Barrett Taksonomisi, anlama sürecini değerlendirmek için geliştirilmişse de diğer disiplinlerdeki akademik ölçümlerde de soruların hazırlanmasında ölçüt olarak kullanılabilmektedir (Yıldırım, 2012).

Okuduğunu anlamayı değerlendirme sürecinde çeşitli soru türleri kullanılmaktadır. Türkçe dersinde açık uçlu, boşluk doldurma, çoktan seçmeli, cümle doğrulama (doğru-yanlış), kısa cevaplı ve eşleştirmeli sorular kullanılmaktadır (Çintaş Yıldız, 2015). Çoktan seçmeli sorularda, öğrenciden verilen seçenekler arasından sorunun doğru cevabının bulunması istenir. Sınıf seviyesine göre seçenek sayısı değişmektedir. Kısa cevaplı sorularda öğrenciden bir kelime, rakam, tarih yazmayı veya en fazla bir cümle ile soruyu cevaplaması beklenir (Tekin, 2000'den aktaran Kan ve Kayapınar, 2006). Açık uçlu sorurlar, diğer türlere göre öğrenciye daha fazla esneklik tanıyan soru türleridir. Burada öğrenci cevabı yapılandırıp, bunun gerekçesini açıklama fırsatı bulmakta ve düşüncelerini özgür bir şekilde ifade edebilmektedir (Gronlund, 1998'den aktaran İlhan, 2016). Cümle doğrulama türü sorularda, verilen metinden seçilen cümlelerin belirli özelliklere göre yeniden yazılması şeklinde düzenlenmektedir. Öğrenciden, verilen cümlelerin metindeki anlamıyla aynı olup olmadığını bulması istenir. Bunun için de verilen cümlenin "Evet-Hayır (Doğru- Yanlış)" şeklinde işaretlemesi beklenir (Ulusoy ve Çetinkaya, 2012). Eşleştirme soruları, genellikle terimlerin ve terimlerin tanımlarının eşleştirilmesi şeklindedir. Öğrenciden bunları eşleştirmeleri istenir. Boşluk doldurma soruları ise verilen cümlede boş bırakılan anahtar kelimelerin doldurulmasını isteyen soru soru türüdür (Çintaş Yıldız, 2015). 
Soru düzeyleri ve türleriyle birlikte soruların cevap kaynakları da okuduğunu anlama sürecinde önemlidir. Bu anlamda Akyol (1997) soruların cevap kaynakları konusunda bir sınıflama yapmıştır. Bu sınıflandırmaya göre sorular; cevabı metin içerisinde, metin dışında ve metinler arasında şeklindedir. Cevabı metin içinde olan sorularda metin içi anlam kurma amaçlanmaktadır. Cevabı metin içerisinde olup ancak direkt verilmeyen, ima edilen ve cevabın bulunması için okuyucunun ön bilgilerini ve deneyimlerini kullanmasını gerektiren sorulardır. Bu sorularda metin dışı anlam kurma amaçlanır. Son olarak sorunun cevaplanabilmesi için farklı kaynaklara başvurmayı gerektiren sorularda da metinler arası anlam kurma amaçlanmaktadır.

Alanyazında okuduğunu anlamaya yönelik sorular üzerinden birçok çalışmaya ulaşmak mümkündür. Bu çalışmalar için alanyazında farklı gruplandırmalar mevcut olmakla birlikte bu çalışmada öğrenciye sunulan materyal (ders kitabı, çalışma kitabı vb.) ve öğretmenlerin hazırladığı sorularla (yazııı sınavlar, çalışma kâğıtları, sınıf içi soruları) yapılan araştırmalar şeklinde bir gruplama yapılmıştır. Birinci grupta öğrenciye sunulan materyaller ile ilgili yapılan araştırmalarda anlamaya yönelik metin altı sorular çeşitli taksonomiler (Bloom Taksonomisi, Barrett Taksonomisi) aracılığıyla incelenmiştir (Akyol, 2001; Özdemir, Özdemir ve Çetinkaya, 2007; Sarar-Kuzu, 2013; Çeçen ve Kurnaz, 2015; Aydoğan ve Aytekin, 2019; Çeliktürk-Sezgin ve Gedikoğlu-Özilhan, 2019; Sallabaş ve Yılmaz, 2020; Üredi ve Ulum, 2020). Bu araştırmalarda incelenen materyallerdeki metin altı soruların önemli bir kısmının basit anlama düzeyinde ve alt düzey bilişsel işlem süreçlerine yönelik, öğrencileri ezbere yönlendiren sorular olduğu sonucuna varılmıştır. Çıkarım yapma, değerlendirme, tahmin etme, yargılama, analiz, sentez gibi üst düzey bilişsel beceriler gerektiren sorulara yer verilmekle birlikte oransal olarak oldukça yetersiz olduğu sonucuna varılmıştır. İkinci grupta ise öğretmenlerin öğrenciye yönelttiği veya sınav gibi materyaller vasıtasıyla hazırladığı sorular, çeşitli taksonomiler (Bloom Taksonomisi, Barrett Taksonomisi) aracılığıyla incelenmiştir (Maden ve Durukan, 2009; Ayvacı ve Türkdoğan, 2010; Aslan, 2011; Ateş, 2011; Akyol vd., 2013; Kavruk ve Çeçen, 2013; Göçer, 2014; Kılınç ve Çalışkan, 2015; Kocaarslan ve Yamaç, 2018; Büyükalan-Filiz ve Delal-Turan, 2018; Uymaz ve Çalışkan, 2019; Karatay ve Dilekçi, 2019). Bu araştırmalarda da öğrenciye sunulan materyallerde elde edilen sonuçlara paralel olarak öğretmenlerin çoğunlukla basit anlama düzeyinde ve alt düzey bilişsel işlem gerektiren sorular sorduğu, öğrencinin çıkarım yapma, değerlendirme, tahmin etme, yargılama, analiz, sentez gibi üst düzey bilişsel becerileri kullanmasını gerektiren sorular sormadığı veya soramadığı sonucuna varılmıştır.

Öğretmenlerin hazırladığı sorulara yönelik çalışmalarda okuduğunu anlamaya yönelik kullandıkları metin altı sorularının soru türü, cevap kaynağı ve düzeyinin çeşitli taksonomiler bakımından araştırıldığı görülmektedir. Özellikle son yıllarda teknolojinin gelişmesiyle birlikte öğretmenler arasında bilgi, belge, materyal paylaşımının arttığı bir gerçektir. Öğretmenlerin hem materyal indirdiği hem de materyal yüklediği ve en sık kullandığı internet sitelerindeki okuduğunu anlamayı değerlendiren metin altı soruların incelendiği bir çalışmaya rastlanmamıştır. Farklı bölgelerde, farklı sosyo-ekonomik çevrelerde çalışan öğretmenlerin sınav ve etkinlik paylaştığı bu platformlardaki okuduğunu anlama metinlerinin ve metin altı sorularının incelenmesinin gerektiği düşünülmektedir.

Bu bağlamda çalışmanın amacı, sınıf öğretmenlerinin okuduğunu anlamaya yönelik hazırladığı metin altı sorularının çeşitli yönlerden incelenmesidir. Bu amaç doğrultusunda aşă̆ıdaki soruların cevapları aranmıştır.

1. Öğretmenler, okuduğunu anlamayı değerlendirmek için hangi metin türlerini tercih etmektedir?

2. Öğretmenler, okuduğunu anlamayı değerlendirmek için hazırlanış türüne göre hangi soruları tercih etmektedir?

3. Öğretmenler, okuduğunu anlamayı değerlendirmek için kullandığı metin altı sorularında hangi cevap kaynaklarını tercih etmektedir?

4. Öğretmenler, okuduğunu anlamayı değerlendirmek için Barrett Taksonomisi'ne göre hangi düzeyde metin altı sorular sormaktadır? 


\section{Araştırmanın modeli}

\section{Yöntem}

Bu çalışma, nitel araştırma yöntemlerinden durum çalışması olarak tasarlanmıştır. Durum çalışmalarında amaç, belli bir duruma ilişkin sonuçları ortaya koymaktır. Burada bir duruma ilişkin etkenler (ortam, birey, süreç, olay) bütüncül yaklaşımla araştırılır ve ilgili durumu nasıl etkiledikleri ile ilgili durumdan nasıl etkilendikleri üzerinde odaklanır (Yıldırım ve Şimşek, 2018). Çalışmada sınıf öğretmenlerinin okuduğunu anlama çalışmalarında ve Türkçe yazılı sınavlarında okuduğunu anlamaya yönelik hazırladıkları metinlerde; metin türleri, metin altı sorularının hazırlanış türüne göre soru tipleri, cevap kaynakları ve düzeyleri çalışılmıştır. Çalışmada öğretmenlerin okuduğunu anlamaya yönelik kullandığı metin ve sorular incelendiğinden; analiz birimi olarak okuduğunu alamaya yönelik metinler ve metin altı sorular seçildiğinden; çalışma, bütüncül tek durum desenli bir durum araştırması olarak tasarlanmıştır. Veriler doküman incelemesi yöntemiyle toplanmıştır. Doküman incelemesi amaçlanan olgu ve olaylar hakkında bilgi içeren yazılı materyallerin analizini kapsar (Yıldırım ve Şimşek, 2018). Bu çalışmanın verileri, öğretmenlerin en sık kullandığı internet sitelerinde öğretmenler tarafından yüklenmiş dosyalardan elde edilmiştir. Doküman analizi yönteminin seçilme nedeni katılımcı tepkiselliğini yani araştırmacı ile öğretmenler arasında doğrudan fiziksel, davranışsal ve duygusal etkileşimin çalışmaya etkisini ortadan kaldırmaktır. Ayrıca daha fazla veriye ulaşmak ve birçok öğretmenin kullandığı verilere ulaşmak yine bu yöntemin seçilme nedenlerindendir.

\section{Örneklem}

$\mathrm{Bu}$ çalışmanın verileri www.egitimhane.com ve www.sinifogretmeniyiz.biz adlı internet sitelerinden 4. sınıflara yönelik okuduğunu anlama çalışmaları ve Türkçe yazılı sınavlarından alınan metinler ile bu metinlere yönelik metin altı sorularından oluşmaktadır. Çalışma kapsamında egitimhane.com ve sinifogretmeniyiz.biz adlı internet sitelerinin seçilmesinin iki nedeni vardır. Birincisi alanyazında öğretmenlerle yapılan çalışmalarda öğretmenlerin en fazla ziyaret ettiği, doküman aldığı ve doküman yüklediği siteler arasında sayılmalarıdır (Tepe, 2020; Işık 2018; Baydaş, Gedik, Göktaş, 2012). Ayrıca Kula ve Demirci-Güler (2019) sınıf öğretmenlerinin ders hazırlıklarında en çok yararlandıkları internet sitesinin egitimhane.com olduğunu ifade etmişlerdir. İkincisi, siteden doküman indirmek için üyelik şartının olmaması ve herkesin kolaylıkla doküman indirebilmesidir. Çünkü öğretmenler, eğitim platformlarını tercih etmelerinin nedenleri arasında bu platformların zengin içeriğe sahip olma, öğrenci seviyesine göre olma, kolayca erişilebilir ve ücretsiz olmalarını saymıştır (Üredi, Akbaşlı ve Ulum, 2016).

\section{Verilerin toplanması}

Egitimhane.com ve sinifogretmeniyiz.biz adlı sitelerinden 2019-2020 öğretim yılında yüklenmiş bütün 4. sınıf yazılı sınavları ve okuduğunu anlamaya yönelik çalışma kâğıtları indirilmiştir. Bu aşamada toplamda 458 çalışmaya ulaşılmıştır.458 çalışmadan 210 tanesi metinleri ve soruları aynı olduğundan çalışmanın dışında bırakılmıştır. Böylece çalışma 248 metin ile yapılmıştır. Metinler, türlerine göre tasnif edilmiştir. Soruların tamamı sıralanarak aynı metne yönelik birbirinin aynısı olan sorular ayıklanmıştır. Son aşamada elde kalan 1377 soru üzerinden analizler yapılmıştır.

\section{Verilerin Analizi}

Verilerin analizinde betimsel analiz yöntemi kullanılmıştır. Metin türleri için hikâye edici, bilgilendirici ve şiir (Akyol, 2010; Güneş, 2019; MEB, 2019) sınıflandırılması esas alınmıştır. Soruların cevap kaynaklarına göre analizinde Akyol'un (1997) cevabı metin içi, metin dışı ve metinler arasında olan sorular şeklindeki sınıflaması esas alınmıştır. Soruların düzeyine göre sınıflandırılması Barrett Taksonomisi'ne göre yapılmıştır. Barrett tarafından geliştirilen taksonomi, anlamanın bilişsel ve duyuşsal boyutlarını kapsamaktadır. "Bu taksonominin geliştirilme sürecinde Barrett, Bloom'un (1956), Sanders'in (1966), Letton'un (1958) ve Guszak'ın (1965) çalışmalarından faydalanmıştır. Bu taksonomide okuduğunu anlama beş farklı kategoriye ayrılmaktadır. Bunlar: basit anlama, yeniden organize etme, derinlemesine anlama, değerlendirme ve memnuniyettir" (Yıldırım, 2013; Akyol vd.,2013). 
Veriler, araştırmacı ve bir sınıf öğretmeni tarafından tek tek incelenerek metin türü, soru türü, cevap kaynağı ve soru düzeyi şeklinde sınıflandırılmıştır. İki kodlayıcı arasında ihtilaf olan maddelerde tekrar ayrı ayrı kodlama yapılmış ve daha sonra uzlaşma sağlanana kadar maddeler incelenmeye devam etmiştir. İki kodlayıcı tam uyum sağlandıktan sonra frekans tablosu oluşturulmuştur.

\section{Araştırmanın Geçerliği ve Güvenirliği}

Nitel araştırmalarda geçerlik ve güvenirlik; inandırıcılık, aktarılabilirlik, tutarlıık ve teyit edilebilirlik kavramlarıyla açıklanmaktadır. Çalışmanın inandırıcılığını artırmak için bulgular kısmında taranan verilerden örnek metinler ve örnek sorulara yer verilmiştir. Aktarılabilirlik özelliğini artırmak için çalışmanın yöntem kısmı açık, anlaşılır ve detaylı bir şekilde verilerek; veri kaynağının seçimi, gerekçeleri, dokümanlara ulaşma, dokümanları sınıflama, çalışmaya dâhil edilen ve dışarda bırakılan verilerin seçimi ve gerekçesi, analiz süreci ayrıntılı bir şekilde okuyucuya ve diğer araştırmacılara sunulmuştur. Araştırma kapsamında incelenen metinlerin ve soruların sınıflandırılmasında araştırmacı dışında bir öğretmenin kodlama yapmasına imkân sağlanmıştır. Metinler, alanyazında göre hikâye edici, bilgilendirici ve şiir türü özelliklerine göre sınıflandırılmıştır. Soruların sınıflandırılmasında ise Barrett Taksonomisi ile yapılmış daha önceki çalışmalardaki örnek sorular da dikkate alınarak her bir soru tek tek taksonomiye göre kodlanmıştır. Teyit edilebilirlik özelliği için çalışma doküman analizi olduğundan katılımcılara yönelik bir işlem yapılmamıştır.

Çalışma doküman analizi yöntemiyle yapıldığından ve internet üzerinden açık kaynaklar kullanıldığından etik kurul iznine başvurulmamıştır.

\section{Bulgular}

Bu bölümde araştırmanın bulgularına yer verilmiştir. Çalışmada cevabı aranan "Öğretmenler, okuduğunu anlamayı değerlendirmek için hangi metin türleri tercih etmektedir?" sorusuna yönelik bulgular Tablo 1'deki gibidir.

Tablo1.

Öğretmenlerin Kullandığı Metin Türleri

\begin{tabular}{lcc}
\hline Metin Türü & $f$ & $\%$ \\
\hline Hikâye Edici Metinler & 173 & 69.7 \\
\hline Bilgilendirici Metinler & 55 & 22.1 \\
\hline Şiir Türü Metniler & 20 & 8.2 \\
\hline Toplam & 248 & 100 \\
\hline
\end{tabular}

Tablo 1'e göre öğretmenler öğrencilerinin okuduğunu anlama becerilerini değerlendirirken en fazla hikâye edici metinleri (\% 69.7) tercih etmektedir. Bunu bilgilendirici metinler (\%22.1) ve şiir türünde metinler (\% 8.2) takip etmektedir.

Hikâye edici türde kullanılan metinlerden biri "Millet Malı" adlı metindir. Metnin bir bölümü şöyledir: "Soğuk, karlı bir hava... Her yer bembeyaz... Bu beyazlığı, yalnız önümüzde giden karartılar bozuyor. Bunlar, kağnılarıyla ordumuza cephane taşıyan köylü kadınlardı. Biraz sonra onlara yetişip selamlaştık. Biz, kalın paltolarımız altında titrerken, çok yaşlı bir nine, yorganını kağnının üstüne örtmüş, çıplak ayaklarıyla karları çiğniyordu..."

Bilgilendirici metin türünde kullanılan metinlerden biri "Televizyon" adlı metindir. Metnin bir bölümü şöyledir:

"Televizyon şüphesiz çok önemli bir iletişim aracıdır. Dünyada olup bitenleri anında haber verir, bize gösterir. Televizyon kitlelerin kültürel değerlerini, bakış açılarını, bilgi hazinelerini etkilemektedir. Ancak televizyon günümüzde yararından daha çok zarar vermektedir. Televizyonun insanlara en büyük zararı zamanlarını boşa harcatmasıdır..." 
Şiir türünde ise "Çocuk ve Ağaç" şiiri örnek verilebilir. Metnin bir bölümü şöyledir: "Çocuk, çok sevdi ağacı... Verirdi ona, her kış. Çiçekleri olaydı! Ağaç, çok sevdi çocuğu... Öperdi altın saçlarından. Dudakları olaydı!"

Çalışmada cevabı aranan "Öğretmenler, okuduğunu anlamayı değerlendirmek için hazırlanış türüne göre hangi tür sorular tercih etmektedir?" sorusuna yönelik bulgular Tablo 2'deki gibidir

Tablo 2.

Öğretmenlerin Hazırlanış Türüne Göre Kullandığı Soru Türleri

\begin{tabular}{lcc}
\hline Soru Türü & $f$ & $\%$ \\
\hline Kısa cevaplı sorular & 943 & 68.48 \\
\hline Çoktan seçmeli sorular & 347 & 25.20 \\
\hline Doğru-yanlış işaretleme soruları & 58 & 4.21 \\
\hline Boşluk doldurma soruları & 27 & 1.96 \\
\hline Cevabı verip soru yazdırma & 2 & 0.15 \\
\hline Toplam & 1377 & 100 \\
\hline
\end{tabular}

Tablo 2'ye göre öğretmenler büyük oranda kısa cevaplı soruları (\%68.48) tercih etmektedir. Kısa cevaplı sorulardan sonra en fazla tercih edilen soru türünün çoktan seçmeli sorular (\% 25.20) olduğu görülmektedir. Az da olsa doğru-yanlış işaretleme soruları (\%4.21), boşluk doldurma soruları (\%1.96) ve cevabı verip soru yazdırma (\%0.15) türünde soruların da sorulduğu görülmektedir.

Öğretmenlerin kullandığı kısa cevaplı sorulara yönelik bazı örnekler şöyledir:

- Nasrettin Hoca neden terliyormuş?

- Anne kunduz, komşusunu uzaklaştırmak için nasıl bir plan yapmıştır?

- Atatürk, Milli Mücadele Dönemi'ndeki başarısını neye bağlıyor?

Öğretmenlerin kullandığı çoktan seçmeli sorulara yönelik bazı örnekler şöyledir:

- Köylü kadının "Millet malı" dediği şey aşağıdakilerden hangisidir?

A) Araba B) Yorgan C) Öküzler D) Cephane

- Insanlar, dostluk ve kardeşlik duygularını ne zaman anlamalıdırlar?

A) gençlik yıllarında B) çocukken C) yaşlanınca D) doğunca

- Bu yazının ana fikri nedir?

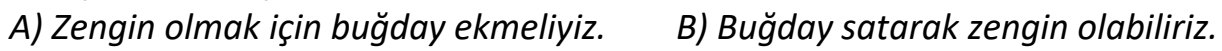

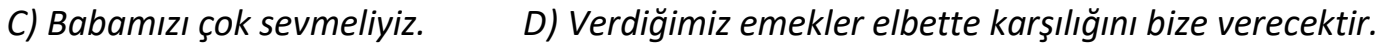

Öğretmenlerin kullandığı doğru-yanlış işaretleme sorularına yönelik bazı örnekler şöyledir:

Metine göre aşağıdaki ifadelerden doğru olanlara " $D$ " yanlış olanlara " $Y$ " yazınız.

-( ) Şerife Bacı, 16 yaşında şehit olmuştur.

- ( ) Inönü Savaşı patlak verince kocasını askere almışlardı.

- ( )Tek korunma aracı olan yün yorganını da top mermilerini ve kızını yağıştan korusun diye, üzerlerine örttü.

Öğretmenlerin kullandığı boşluk doldurma sorularına yönelik bazı örnekler şöyledir:

- Rüyasını anlatmış ve getirilmesini istemiş.

- Hasan'ın piknik yapmayı çok sevmesine ablası hoşlanmazdı.

Öğretmenlerin kullandığı cevabı verip soru yazdırmaya yönelik bazı örnekler şöyledir:

- Metinle ilgili bir soru da siz yazıp, cevaplayınız.

Yanitın sorusunu yazalım

Soru:

?Yanıt: Çocuk, arkadaşlarından ayrılacağı için üzülüyordu

Çalışmada cevabı aranan "Öğretmenler, okuduğunu anlamayı değerlendirmek için kullandığı metin altı sorularında hangi cevap kaynaklarını tercih etmektedir?" sorusuna yönelik bulgular Tablo 3'teki gibidir 
Tablo 3.

Soruların Cevap Kaynakları

\begin{tabular}{lcc}
\hline Cevap kaynağı & $\mathrm{f}$ & $\%$ \\
\hline Metin içi & 1346 & 97.75 \\
\hline Metin dışı & 31 & 2.25 \\
\hline Metinler arası & 0 & 0.00 \\
\hline Toplam & 1377 & 100 \\
\hline
\end{tabular}

Tablo 3'e göre öğretmenlerin sorduğu soruların büyük bölümünün $(\% 97,75)$ cevap kaynaklarının metin içinde olduğu, çok az kısmının ise $(\% 2,25)$ cevap kaynaklarının metin dışında olduğu görülmektedir. Metinler arası cevap kaynağı olarak herhangi bir soru sorulmamıştır. Metin içi sorulara örnek olarak şu sorular verilebilir:

- Ayşe doğum günü için hazırladığı davetiyeleri ne zaman arkadaşlarına vermiştir?

- Insanların kullandıktan sonra bir köşeye attıkları şeyler nelerdir?

- Yazar çocukluğunda hangi oyunları oynuyormuş?

Metin dışı sorulara örnek olarak şu sorular verilebilir:

- Kuş yakalayıp kafese hapseder miydiniz? Düşüncelerinizi yazınız.

- Yürüyemiyor olsaydınız okulda ne gibi zorluklarla karşılaşırdınız?

- Bir ailede olması gereken en önemli değerler nelerdir?

Çalışmada cevabı aranan "Öğretmenler, okuduğunu anlamayı değerlendirmek için hangi düzeyde metin altı sorular sormaktadır?” sorusuna yönelik bulgular Tablo 4'teki gibidir.

Tablo 4.

Soruların Barrett Taksonomi'sine Göre Sınıflandırılması

\begin{tabular}{lcc}
\hline Düzey & $f$ & Yüzde \\
\hline Basit anlama & 1183 & 85.91 \\
\hline Yeniden organize etme & 25 & 1.82 \\
\hline Derinlemesine anlama/ Çıkarımsal anlama & 144 & 10.46 \\
\hline Değerlendirme & 13 & 0.94 \\
\hline Memnuniyet & 12 & 0.87 \\
\hline Toplam & 1377 & 100 \\
\hline
\end{tabular}

Tablo 4'e göre öğretmenlerin okuduğunu anlamayı değerlendirirken en fazla kullandığı soru türü basit anlama (\%85.91) düzeyinde sorular iken en az kullandığı soru türü ise değerlendirme $(\% 0.94)$ ve memnuniyet $(\% 0.87)$ kategorisindeki sorulardır. Ayrıca derinlemesine anlam çıkarma/çıkarımsal anlama (\%10.46) ve yeniden organize etme (\%1.86) soruları da basit anlama düzeyindeki soru oranına göre oldukça düşüktür.

Öğretmenlerin basit anlama düzeyinde kullandığı sorulara bazı örnekler şöyledir:

- Atatürk, Tarsus'a ne zaman gitmiş?

-(D/Y ) 1984, 1985 ve 1986'da dünyada yılın haltercisi seçildi.

- Kartal yuvasını nereye yapmıs??

Yeniden organize etme düzeyinde soruların tamamın yakını metne başlık koyma şeklindedir. Öğretmenler yeniden organize etme düzeyinde kullandığı sorulara bazı örnekler şöyledir:

- Özgür'ün kişilik özelliklerini yazınız.

- Metne uygun bir başık yazınız

- Metni, 10 tümceyi(cümleyi) geçmeyecek şekilde defterinize okunaklı yazarak özetleyiniz. 
Öğretmenlerin, derinlemesine anlama/ çıkarımsal anlama düzeyinde kullandığı sorulara bazı örnekler şöyledir:

- Okuduğunuz metnin ana fikri (asıl anlatılmak istenen) nedir?

- Şiirin ana duygusu aşağıdakilerden hangisidir?

- Metinde geçen "Görüşleri, tutum ve davranışları birbirine uygun." anlamına gelen deyim hangisidir?

Öğretmenlerin değerlendirme düzeyinde kullandığı sorulara bazı örnekler şöyledir:

- Yürüyemiyor olsaydınız okulda ne gibi zorluklarla karşılaşırdınız?

- Aileniz sizin için ne ifade etmektedir? Düşünüp yazalım

- Dostluk ve kardeşlik sözcükleri bize neler düşündürüyor?

Öğretmenlerin memnuniyet düzeyinde kullandığı sorulara bazı örnekler şöyledir:

- Kuş yakalayıp kafese hapseder miydiniz? Düşüncelerinizi yazınız.

- Ağaca çıkan kişinin yerinde sen olsaydın ne yapardın?

- Film seçimleri doğru muydu? Size göre şiirde bahsi geçen çocuklar nasıl filmler seçmeliydi?

\section{Tartışma ve Sonuç}

Okuduğunu anlamaya yönelik metin altı soruları öğrencilerin okuduğunu anlama becerisini ölçme ve değerlendirme imkânı sağlamakla birlikte öğrencinin düşünme becerisinin gelişiminde etkilidir. Metin altı sorular aracılı̆ıyla öğrenciler okumaya odaklanarak ve metnin derinliklerine inerek anlam kurar, okuduğunu eleştirel bir şekilde yansıtmasını sağlar (Hervey, 2006; Akyol vd., 2013). Metin altı sorularla birlikte bireyin okuduğunu daha iyi anlaması sağlanırken aynı zamanda yaratıcılık, eleştirme, sorgulama, analiz, sentez, değerlendirme gibi üst düzey düşünme becerilerinin gelişimi de desteklemektedir. Soruların önemi, öğretmenlerin sordukları soruların amacına hizmet etme düzeyini de önemli kılmaktadır. Çünkü ilkokul düzeyinde okuma ve okuduğunu anlama çalışmaları öğrencinin bundan sonraki anlama sürecinin temelini oluşturmaktadır. Bu süreçte öğretmenlerin metin seçimi, soru türleri, cevap kaynakları ve soru düzeyleri öğrencinin hem okuduğunu anlama becerisini ortaya koyarken hem de düşünme becerisini geliştirmekte ve sonraki aşamalar için hazırbulunuşluk düzeyini arttırmaktadır.

$\mathrm{Bu}$ çalışmada elde edilen sonuçlardan birincisi metin türleriyle ilgilidir. Öğretmenlerin okuduğunu anlamaya değerlendirmek için en fazla hikâye edici metinleri kullandığı, ikinci sırada bilgilendirici metinlere yer verdiği ve şiir türünde metinlere ise daha az yer verdiği sonucuna ulaşılmıştır. Benzer şekilde yapılan çalışmalarda (Çeliktürk-Sezgin ve Gedikoğlu-Özilhan 2019; Kocaarslan ve Yamaç, 2018) çoğunlukla hikâye edici ve bilgilendirici metinlere yer verildiği sonucuna ulaşmışlardır. İlkokul öğrencileri için yaş düzeyleri dikkate alındığında hikâye edici metinler diğer türlere göre daha kolay anlaşılırdır. Öğrenci bu metin türüne günlük hayatta zaten aşina olduğundan metni anlamakta hem zorlanmaz hem de metne yönelik daha olumlu tutumlar sergiler. Öğretmenlerin hikâye edici metinleri daha çok tercih etmesinin nedenlerinden birinin öğrencilerin hikâye edici metin türüne aşina olmasıyla ilgili olduğu düşünülmektedir.

Çalışmada elde edilen sonuçlardan ikincisi metin altı soruların hazırlanış şekline göre soru türleridir. Çalışmada elde edilen sonuca göre öğretmenler büyük oranda kısa cevaplı soruları ve çoktan seçmeli soruları tercih etmiştir. Cümle doğrulama (Doğru-yanlış), boşluk doldurma ve cevabı verip soru yazdırma gibi sorulara yer verilmekle birlikte bunların oranı oldukça düşüktür. Yapılan çalışmalar incelendiğinde en fazla kısa cevaplı (Maden ve Durukan, 2009; Kocaarslan ve Yamaç, 2018; Akyol, 2001) ve çoktan seçmeli sorulara (Karatay ve Dilekçi, 2019; Maden ve Durukan, 2009;Akyol, 2001) yer verildiği görülmektedir. Bu çalışmalardan farklı olarak Aytekin ve Aydoğan (2019) yaptığı çalışmada yabancı dil olarak Türkçe öğretiminde kullanılan okuma metinleri ve metin altı sorularını incelediği çalışmada çoğunlukla açık uçlu sorulara, doğru-yanlış ve boşluk doldurma sorularına yer verildiğini tespit etmiştir. Hynds'a (1990'dan aktaran Akyol, 1997) göre öğrencilerin okuma parçalarından anlam kurmaları; açık uçlu, çok yönlü ve öğrenciyi merkeze alan sorular yerine, kısa cevaplı sorularla sınırlanırsa okuma metinleri hakkında öğrenecekleri de sınırlandırımış olur. Bu sonuçlarla öğretmenlerin, öğrencilerin anlam kurmalarını sınırlandırdığı söylenebilir. Ayrıca 
öğretmenlerin soru çeşitliliğini kullanmakla birlikte hazırlanışı ve değerlendirmesi daha kolay soruları tercih ettiği şeklinde değerlendirilebilir. Özellikle ülkemizde sınıfların kalabalık olduğu düşünüldüğünde öğretmenlerin değerlendirmeden zaman kazanmak için değerlendirmesi daha kolay soru tiplerini tercih ettiği düşünülmektedir. Çünkü kısa cevaplı sorular ve çoktan seçmeli soruların, değerlendirme bakımından açık uçlu sorulara göre daha kolay olduğu düşünülmektedir.

Çalışmada elde edilen sonuçlardan üçüncüsü, soruların cevap kaynağının tercih edildiği yer ile ilgilidir. Öğretmenlerin sorduğu soruların neredeyse tamamının cevap kaynağının metin içinde olduğu görülmektedir. Çok az sayıda metin dışına yönlendiren soru olmakla birlikte metinler arası cevap kaynağı olan soru bulunmamaktadır. Benzer şekilde yapılan çalışmalarda (Akyol, 2001; Güfta ve Zorbaz, 2008; Akyol vd., 2013; Ateş, Güray, Döğmeci ve Gürsoy, 2016; Kocaarslan ve Yamaç, 2018; Çeliktürk-Sezgin ve Gedikoğlu-Özilhan 2019) hem basılı materyallerde hem de öğretmenlerin sordukları soruların önemli bir kısmının cevap kaynağının metin içinde olduğu tespit edilmiştir. Bunun en önemli nedeni öğretmenlerin soru sorma konusunda yetersiz olmasıyla ilgili olabilir. Çünkü soruların kullanımıyla ilgili öğretmen/öğretmen adayları desteğe ihtiyaç duymaktadır (Karatay ve Dilekçi, 2019; Akyol, vd., 2013; Doğanay ve Yüce, 2010). Bunula birlikte belirli bir eğitim sonucunda öğretmenlerin soru sorma becerileri geliştirilebilmektedir (Aslan, 2011). Öğretmenler soru sorma konusunda yetersiz olduğundan eldeki kaynaklardan soruyu birebir kopyalayıp veya metne uyarlayarak sormuş olabilir. Bu çalışmanın araştırma alanına girmemekle birlikte bu çalışmadan elde edilen bir sonuç bunu doğrulamaktadır. Bu çalışma için ulaşılan 458 çalışmadan 210 tanesi metinleri ve soruları aynı olduğundan çalışmanın dışında bırakılmıştı. Çünkü birçok Türkçe yazılı sınav kâğıdının (farklı kişilerce hazırlanmasına rağmen) metinleri ve sorularının aynı olduğu görülmüştür.

Çalışmada elde edilen sonuçlardan dördüncüsü öğretmenlerin sorduğu soruların Barrett Taksonomisi'ne göre düzeyleriyle ilgilidir. Öğretmenlerin okuduğunu anlamayı değerlendirirken büyük oranda basit anlama düzeyinde sorular sorduğu görülmektedir. Derinlemesine anlam çıkarma/çıkarımsal anlama sorularına kısmen yer verilmekle birlikte, yeniden organize etme, değerlendirme ve memnuniyet kategorisindeki sorular yok denecek kadar azdır. Soruların önemli bir kısmı basit düzeyde anlama gerektiren sorularıdır. Yapılan çalışmalara bakıldı̆̆ında bu çalışmayla uyumlu olarak (Maden ve Durukan, 2009; Ayvacı ve Türkdoğan, 2010; Aslan, 2011; Ateş, 2011; Akyol vd., 2013; Kavruk ve Çeçen, 2013; Göçer, 2014; Kılınç ve Çalışkan, 2015; Kocaarslan ve Yamaç, 2018; Karatay ve Dilekçi, 2019) öğretmen/öğretmen adaylarının sorduğu soruların alt düzeyde kaldığı, üst düzey soru sormakta ciddi sorun olduğu görülmüştür. Akyol'a (1997) göre üst düzey bilişsel süreçlerin kullanımını gerektiren sorular öğrencileri bağımsız düşünmeye yöneltirken, basit anlama düzeyindeki sorular önceden kazanılan veya verilen bilginin hatırlanmasını gerektirmektedir. Buradan öğretmenlerin öğrencilerin bağımsız düşünme yerine daha çok bilginin hatırlanması yönelik sorular sorduğu sonucu çıkarılabilir. Bu sonucun birkaç nedeninin olduğu düşünülmektedir. Birincisi öğretmenlerin soru sorma konusundaki yetersizliğidir. Alanda yapılan birçok çalışma bunu kanıtlamaktadır. Karatay ve Dilekçi (2019) de benzer şekilde yaptıkları çalışmada öğretmenlerin basit anlama ve kavrama düzeyinde sorular sormasının, soru hazırlama konusunda yeterliklerinden ve öğrencilere kolay soru sunarak yüksek başarı puanı verme kaygısından kaynaklanmış olabileceğini ifade etmektedir. Gerek hizmet öncesinde gerek hizmet içinde öğretmenlerin soru sorma becerisinin geliştirilmesinde bir takım sorunlar olduğu düşünülmektedir. i̇kincisi öğretmenlerin örnek soru olarak göreceği ve kendi sorularını da karşılaştıracağı ders kitabı, çalışma kitabı ve diğer kaynaklardaki metin altı soruların da benzer şekilde basit anlama düzeyinde kalması ve üst düzey becerilere yönelik soruların sınırlı olmasıdır. Bu anlamda alanyazında kaynak kitapların metin altı sorularının durumunu ortaya koyan çokça çalışma bulunmaktadır (Akyol, 2001; Özdemir vd., 2007; Çeçen ve Kurnaz, 2015; Çeliktürk-Sezgin ve Gedikoğlu-Özilhan, 2019). Üçüncüsünün öğretmenlerin değerlendirmeye ayırdığı zamanla ilgili olduğu düşünülmektedir. Basit anlama düzeyi soruları ve bunlara yönelik soru tipleri (kısa cevaplı, çoktan seçmeli vb.) ile metin içine yönelik soruların ağırlıklı olması öğretmenlerin özellikle kalabalık sınıflarda değerlendirmede zaman kazanmak amacıyla bu sorulara yöneldiğine işaret olabilir. Çünkü öğretmenler, basit anlama gerektiren ve tek cevabı olan hatta cevabı metin içinde olan soruları daha kolay puanlar. Ancak metin dışı ve metinler arası sorular ile değerlendirme ve memnuniyet kategorisindeki soruların cevaplarının her bir öğrencide farklı olacağı düşüldüğünde 
öğretmenlerin bütün cevapları tek tek okuması ve değerlendirmesini gerektirecektir. Çalışmada soruların cevap kaynağının tamamına yakınının metin içinde olması ve basit anlama düzeyinde soruların yüksek oranda çıkması buna bir işaret olabilir. Özellikle son yıllarda yardımcı kaynaklar (MEB'in ders kitapları dışında) kare kod ve optik okuma gibi yöntemlerle öğretmenlerin ölçme ve değerlendirme işini kolaylaştırmıştır. Bu yöntemlerle öğretmenler, örneğin 40 öğrencinin cevaplarını birkaç dakika içinde okuyup hatta sınıfın raporlarına ulaşabilmektedir. Bu durum öğretmenler için bir rahatlama sağlamış ve daha kolay olanı tercih etmeye yöneltmiş olabilir. Bu nedenle her bir öğrencinin cevabının tek tek okunduğu, çok farklı cevapların olacağı, hatta bazı cevaplarda öğretmenin metni tekrar okuyup değerlendirme yapacağı üst düzey düşünme beceri gerektiren sorular daha az tercih edilebilir. Dördüncüsü ise çevrimiçi öğretmen sitelerinin bilgi/belge paylaşımına olanak vermesiyle öğretmenlerin istediği metinlere ve sorulara hemen ulaşabilmesi, aynı sınıfı okutan diğer öğretmenlerin yaptığı çalışmalara ulaşarak direkt kullanması veya benzer örnekleri oluşturmasıyla ilgili olabilir.

Son yıllarda TIMMS, PISA, PIRSL vb. uluslararası sınavlarda Türk öğrencilerin okuduğunu anlama becerileri ile ilgili çokça tartışma yapılmaktadır. Akyol vd. (2013) Türk öğrencilerin uluslararası sınavlarda üst düzey düşünmeyi gerektiren sorulardaki durumunu öğretim sürecinde ve yazılı materyallerde karşılaştıkları soruların düzeyi ile de ilişkili olduğunu ifade etmektedir. Öğrenciler özellikle ilkokulda bu tür sorularla karşılaşmamış, öğretme sürecinde okuduğunu anlama çalışmaları bu sorularla yapılmamış ve öğrencilerin üst düzey düşünme becerileri geliştirmemişse üst düzey sorularda başarılı olması beklenemez.

\section{Öneriler}

\section{Uygulayıcılar için;}

- Öğretim sürecinde çeşitli metin türlerine yer verilerek öğrencilerin her metin türüyle karşılaşması sağlanmalıdır.

- Öğretim sürecinde ve ölçme-değerlendirme aşamasında hazırlanış yöntemine göre soru çeşitliliği artırılmalıdır.

- Soruların cevap kaynağına yönelik çeşitlilik artırılarak üst düzey düşünme becerileri desteklenmelidir.

- Hem kaynak kitaplarda hem de sınav ve okuduğunu anlama çalışmalarında metin altı sorularda soruların düzeyine göre dengeli bir dağılımı sağlanmalıdır.

- Öğretmenlere ve öğretmen adaylarına öğrencilerin üst düzey düşünme becerilerinin gelişimini destekleyecek öğretim yapmaları ve soru hazırlama teknikleri konusunda hizmet öncesi ve hizmet içi eğitimler verilmelidir.

\section{Araştırmacılar için;}

- Öğretmenlerin soru hazırlamasında ve uygulamasındaki yetersizliklerinin nedenleri araştırılmalıdır.

- Öğretmenlerin soru sorma becerisinin geliştirilmesi için çalışmalar yapılmalıdır.

\section{Kaynaklar}

Akyol, H. (2001). İlköğretim okulları 5. sınıf Türkçe ders kitaplarındaki okuma metinleriyle ilgili soruların analizi. Kuram ve Uygulamada Eğitim Yönetimi, 26, 169-178.

Akyol, H. (2003). Metinlerden anlam kurma. TÜBAR, XIII, 49-58.

Akyol, H. (2010) Yeni programa uygun Türkçe öğretim yöntemleri. Ankara, Pegem Akademi Yayınları. Akyol, H. (2018). Türkçe ilk okuma yazma öğretimi. Ankara: Pegem Akademi.

Akyol, H., Yıldırım, K., Ateş, S. \& Çetinkaya, Ç. (2013). Anlamaya yönelik nasıl sorular soruyoruz? Mersin Üniversitesi Eğitim Fakültesi Dergisi, 9(1), 41-56.

Akyol, H. (1997). Okuma metinlerindeki soruların sınıflandırılması. Eğitim ve Bilim, 21(105), 10- 17.

Aslan, C. (2011). Soru sorma becerilerini geliştirmeye dönük öğretim uygulamalarının öğretmen adaylarının soru oluşturma becerilerine etkisi. Eğitim ve Bilim, 36, 236-249. 
Ateş, S. (2011). Illköğretim Beşinci Sınıf Türkçe Dersi Öğrenme-Öğretme Sürecinin Anlama Öğretimi Açısından Değerlendirilmesi. Yayınlanmamış doktora tezi. Gazi Üniversitesi Eğitim Bilimleri Enstitüsü, Ankara

Ateş, S., Güray, E., Döğmeci, Y., \& Gürsoy, F. (2016). Öğretmen ve öğrenci sorularının gerektirdikleri zihinsel süreçler açısından karşılaştırılması. Okuma Yazma Eğitimi Araştırmaları, 4 (1), 0-0.

Ateş, S. ve Yıldııım, K. (2014). Sınıf öğretmenlerinin okuma becerisine yönelik uygulamaları: Strateji öğretimi ve anlama. ilköğretim Online, 13, 235-257.

Aydoğan, K. ve Aytekin, H. (2019). Yabancı dil olarak Türkçe öğretiminde set halinde kullanılan 'İstanbul' metot kitaplarında okuma metinleri ve metin altı soruları üzerine bir değerlendirme. The Journal of International Social Research, 12, 67, 10 / 2019.

Ayvacı, H. Ş. ve Türkdoğan, A. (2010). Yeniden yapılandırılan Bloom Taksonomisi'ne göre fen ve teknoloji dersi yazılı sorularının incelenmesi. Türk Fen Eğitimi Dergisi, 7(1), 13-25.

Baydaş, Ö., Gedik. N., \& Göktaş, Y. (2012, Mayıs). İlköğretim okullarındaki öğretmenlerin bilişim teknolojilerini kullanma durumu. IV. Uluslararası Türkiye Eğitim Aştırmaları Kongre Kitabı (ss. 402-410). İstanbul: Yıldız Teknik Üniversitesi.

Büyükalan Filiz, S. ve Delal Turan, S. (2018). 4. sınıf öğretmenlerinin temel derslerde sordukları yazılı sınav sorularının Bloom Taksonomisi açısından incelenmesi. Asya Studies, 5 (5) , 11-20.

Çintaş Yıldız, D. (2015). The analysis of Turkish course exam questions according to re-constructed Bloom's Taxonomy. Gaziantep University Journal of Social Sciences, 14 (2) , 479-497.

Çeçen, M. A. ve Kurnaz, H. (2015). Ortaokul Türkçe dersi öğrenci çalışma kitaplarındaki tema değerlendirme soruları üzerine bir araştırma. Karadeniz Sosyal Bilimler Dergisi, 7(02).

Çeliktürk Sezgin, Z. ve Gedikoğlu Özilhan, Y. G. (2019). 1.-8. Sınıf Türkçe ders kitaplarındaki metne dayalı anlama sorularının incelenmesi. Ana Dili Eğitimi Dergisi, 7(2), 353-367

Day, R. R. ve Park, J. (2005). Developing reading comprehension questions. Reading in a Foreign Language, 17(1), 60-73.

Doğanay, A. ve Yüce, S. G. (2010). Öğrencilerin düşünme becerilerinin geliştirilmesinde rehberli yardım: Bir öğretmenin sözel ifadelerinin analizine ilişkin durum çalışması. Kuram ve Uygulamada Eğitim Yönetimi, 16, 185-214.

Dolapçıŏlu, S. (2020). Düşünen sınıf materyallerinin (DSM) PISA okuma becerileri üzerinde etkisi. Ana Dili Eğitimi Dergisi, 8(1), 196-210.

Göçer, A. ve Şentürk, R. (2019). Türkçe eğitiminde yazma becerilerini geliştirmeye yönelik kullanılabilecek geribildirim türleri. Yüzüncü Yıl Üniversitesi Sosyal Bilimler Enstitüsü Dergisi, (43) , 123-149.

Göçer, A. (2014). The Assessment of Turkish written examination questions based on the text in accordance with the Barrett's Taxonomy. International Journal of Languages' Education and Teaching, 3, 1-16.

Güfta, H. ve Zorbaz, K. Z. (2008). Illköğretim ikinci kademe Türkçe dersi yazılı sınav sorularının düzeyleri üzerine bir değerlendirme. Çukurova Üniversitesi Sosyal Bilimler Enstitü Dergisi, 17, 205-218.

Güneş, F. (2009). Türkçe öğretiminde günümüz gelişmeler ve yapılandırıcı yaklaşım. Mustafa Kemal Üniversitesi Sosyal Bilimler Enstitüsü Dergisi, Yıl/Year: 2009 Cilt/Volume:6 Sayı/Issue: 11,1-21.

Güneş, F. (2019). Türkçe öğretimi yaklaşımlar ve modeller. Ankara: Pegem Akademi Yayıncılık.

Hervey, S. (2006). Who asks the questions? Teaching PreK-8, 37, 68-69.

Işık, A. (2018). The abilities of primary teachers to design e-learning content: Sample of NEIT. Sınırsız Eğitim ve Araştırma Dergisi, 3 (2) , 17-28.

İlhan, M. (2016). Açık uçlu sorularla yapılan ölçmelerde klasik test kuramı ve çok yüzeyli Rasch modeline göre hesaplanan yetenek kestirimlerinin karşılaştırılması. Hacettepe Üniversitesi Eğitim Fakültesi Dergisi, 31(2), 346-368.

Kan, A. ve Kayapınar, U. (2006). Yabancı dil eğitiminde aynı davranışları yoklayan çoktan seçmeli ve kısa cevaplı iki testin madde ve test özelliklerinin karşılaştırılması. Eğitim ve Bilim, 31(142).

Karatay, H. ve Dilekçi, A. (2019). Türkçe öğretmenlerinin dil becerilerini ölçme ve değerlendirme yeterlikleri. Milli Eğitim Dergisi,48(1), 685-716. 
Kavruk, H. ve Çeçen, M.A. (2013). Türkçe dersi yazılı sınav sorularının bilişsel alan basamakları açısından değerlendirilmesi. Ana Dili Eğitimi Dergisi, 1(4), 1-9.

Kılınç, G. ve Çalışkan, H. (2015). Sosyal bilgiler öğretmenlerinin sınıf içi ders işleme sürecindeki soru sorma davranışlarının değerlendirilmesi. Abant İzzet Baysal Üniversitesi Eğitim Fakültesi Dergisi, 15 (USBES Özel Sayısı I),265-286.

Kocaarslan, M. ve Yamaç, A. (2018). Sınıf öğretmenlerinin Türkçe dersi sınavlarında sordukları metne dayalı anlama sorularının incelenmesi. Trakya Üniversitesi Eğitim Fakültesi Dergisi, 8(2), 431448.

Koçak, A. (2005). Bolu ili Illköğretim Beşinci ve Sekizinci Sınıf Öğrencilerinin Yazılı Anlatım Becerileri Üzerine Bir Araştırma. (Yayımlanmış yüksek lisans tezi). Abant İzzet Baysal Üniversitesi, Bolu

Kula, S. ve Demirci Güler, M. (2019). Sınıf öğretmenlerinin interneti eğitim amaçlı kullanma durumları. Yüzüncü Yıl Üniversitesi Eğitim Fakültesi Dergisi, 16 (1) , 620-647.

Maden, S. ve Durukan, E. (2009). Türkçe dersi yazılı sorularının öğrenme alanlarına, soru tiplerine ve taksonomilerine göre değerlendirilmesi (Erzurum Ili Örneği). Kâzım Karabekir Eğitim Fakültesi Dergisi, 95-115.

Milli Eğitim Bakanlı̆̆ı. (2019). Türkçe dersi (1-8. Sınıflar) öğretim programı. Ankara: MEB.

Özdemir, M., Özdemir, O., \& Çetinkaya, Ç. (2007, Kasım). Illköğretim 1-5 sınıflar Türkçe çalışma kitaplarındaki soruların analizi. İlköğretim Kongresi'nde sunulmuş sözlü bildiri. Hacettepe Üniversitesi, Ankara.

Sallabaş, M. ve Yılmaz, G. (2020). Türkçe ders kitabında bulunan metin altı sorularının Yenilenmiş Bloom Taksonomisi'ne göre incelenmesi. Ana Dili Eğitimi Dergisi, 8 (2) , 586-596.

Sarar Kuzu, T. (2013). Türkçe ders kitaplarındaki metin altı sorularının yenilenmiş Bloom Taksonomisi'ndeki hatırlama ve anlama bilişsel düzeyleri açısından incelenmesi. CÜ Sosyal Bilimler Dergisi, 37(1), 58-76.

Temizkan, M. ve Sallabaş, M. (2011). Okuduğunu anlama becerisinin değerlendirilmesinde çoktan seçmeli testlerle açık uçlu yazııı yoklamaların karşılaştııılması. Dumlupınar Üniversitesi Sosyal Bilimler Dergisi,(30),207-220.

Tepe, N. (2020). Blogs on education examination of teachers' use cases and thoughts. Journal of Human Sciences, 17(1), 162-171.

Ulusoy, M. ve Çetinkaya, Ç. (2012). Cümle doğrulama tekniğinin okuma ve dinlemenin ölçülmesinde kullanılması. Hacettepe Üniversitesi Eğitim Fakültesi Dergisi, 43, 460-471.

Uymaz, M. ve Çalışkan, H. (2019). Öğretmen yapımı sosyal bilgiler dersi sınav sorularının Yenilenmiş Bloom Taksonomisi'ne göre incelenmesi. Kastamonu Eğitim Dergisi, 27 (1) , 331-346.

Üredi, L., Akbaşlı, S. \& Ulum, H. (2016). Investigating the primary school teachers' perspectives on the use of education platforms in teaching. Educational Research and Reviews, 11(15), pp.14321439.

Üredi, L. ve Ulum, H. (2020). Illkokul matematik ders kitaplarında bulunan ünite değerlendirme sorularının Yenilenmiş Bloom Taksonomisi'ne göre incelenmesi. Mersin Üniversitesi Eğitim Fakültesi Dergisi, 16 (2) , 432-447.

Yıldııım, A. \& Şimşek, H. (2018). Nitel araştırma yöntemleri. Ankara: Seçkin Yayıncılık

Yıldırım, K. (2013). Öğretmenlerin öğrencilerin okuduğunu anlama becerilerini değerlendirmede kullanabilecekleri bir sistem: Barrett Taksonomi'si/A system to be used by teachers to evaluate students' reading comprehension skills: Barrett Taxonomy . Mustafa Kemal Üniversitesi Sosyal Bilimler Enstitüsü Dergisi, 9 (18), 45-58.

\section{Extended Abstract}

Introduction

Reading, which is one of the basic language skills, is defined as "the process of making sense in a regular environment, in line with an appropriate method and purpose, using pre-knowledge, based on effective communication between author and reader" (Akyol, 2018). The purpose in reading is to understand, that is to establish the meaning (Akyol, 2001; Akyol 2003). With the reading activity, the person is expected to make sense of the text directly or indirectly. Reading 
comprehension can be defined as a tool not only for learning academic information but also for lifelong learning (Ateş \& Yıldırım, 2014). Various methods are used to determine the reading comprehension level of the individual. Among these methods, one of the oldest and most frequently used methods is to ask questions about the material read. In primary school, which is one of the most important periods of the development of reading skills, primary school teachers frequently use sub-text questions in reading comprehension to improve reading and reading comprehension skills especially in Turkish classes. In the literature, it is possible to reach many studies through the questions about reading comprehension. It is seen that the question type, source of the answer and level of the text-based reading comprehension questions are used by teachers to understand what they read in their studies for the questions they prepared were investigated in terms of various taxonomies. It is a fact that with the development of technology in recent years, the sharing of information, documents and materials among teachers have increased. There is not a survey that examines text-based reading comprehension questions evaluating reading comprehension on the websites where teachers both download and upload materials and use these materials frequently. It is thought that the reading comprehension texts and text-based reading comprehension questions in these platforms where teachers working in different regions and different socio-economic environments share exams and activities should be examined.

\section{Method}

The present study aimed to investigate text-based reading comprehension questions prepared by primary school teachers. This study was designed as a case study, which is one of the qualitative research methods. The data have been collected via the document analysis method. The data collected from the websites of "www.egitimhane.com" and "www.sinifogretmeniyiz.biz". The data were comprised of reading comprehension activities prepared for 4th-grade students and texts are taken from Turkish written exams. The data consisted of texts and text-based questions. The main reason why the websites at egitimhane.com and sınifogretmeniyiz.biz were included in the study was that they are the most visited websites where teachers download and upload documents (Tepe, 2020; Işık, 2018; Baydaş, Gedik, Göktaş, 2012). The second reason was that visitors do not need to sign up to download documents from these websites. During the data collection phase, the following method was followed: all documents (458 documents) uploaded to the websites of egitimhane.com and sinifogretmeniyiz.biz during the 2019-2020 academic year were downloaded. 210 of these 458 documents were excluded from the study since texts and questions were the same. Thus, 248 texts were included in the survey. Texts were classified according to type. All questions were listed and the same questions on the same text were excluded. In the last stage, the remaining texts and questions were analyzed.

A descriptive analysis method was used for data analysis. Text types were based on narrative, informative, and poetry (Akyol, 2010; Güneş, 2019; MEB, 2019) classification. While analyzing questions by source of the answer, a classification based on intratextual, intertextual, and nontextual questions was used. The classification of question levels was based on Barrett Taxonomy. Reading comprehension is divided into five different categories in this taxonomy. These categories are literal comprehension, reorganization, inferential comprehension, evaluation, and appreciation (Yıldırım, 2013; Akyol et al., 2013).

The data were analyzed individually by the researcher and a classroom teacher, and they were classified as text type, question type, source of the answer, and question level. The items that conflicted between two coders were coded again. The items were analyzed until a consensus was reached. The frequency table was formed after two encoders fully matched.

In qualitative studies, validity and reliability are explained by credibility, transferability, consistency and conformability (Yıldırım and Şimşek, 2018). To ensure credibility in the survey, sample texts and sample questions from reviewed data were included. To ensure transferability, the method section in the study was presented in a clear, comprehensible, and detailed way. Phases such as selecting the data source and justifications, accessing documents, classifying documents, selecting the data included and excluded and justifications, the analysis process were presented to 
the reader and other researches in an in-depth fashion. In the classification of texts and questions analyzed in the study, a teacher, apart from the researcher, coded the items. For conformability, no process was conducted for participants since the study was based on document analysis.

\section{Result and Discussion}

The first conclusion in present survey is related to text types. Teachers use narrative texts the most to evaluate reading comprehension. The second most used text type is informative texts and the third one is poetry. The second conclusion is related to question types. As a result of the survey, It was found that teachers mostly prefer short answer questions and multiple-choice questions. Although they also use question types such as true-false, fill-in-the-blank questions, providing answers and asking for the question, their frequency is rather low. The third conclusion is related to the source of the answer in questions. The answers of almost all the questions asked by teachers can be found in the text itself. Very few questions direct students outside of the text. No question type could be answered in an intertextual manner. The fourth conclusion is related to the levels of these questions according to Barrett Taxonomy. Teachers mostly ask questions at a literal comprehension level. Questions related to inferential comprehension are partially used. There are very few questions related to categories such as reorganization, evaluation, and appreciation. An important part of these questions are questions that require a simple level of reading comprehension.

In line with these conclusions, suggestions were made for researchers and practitioners. Accordingly, several text types must be included in the teaching process, and students should be introduced to every text type. During the teaching process and assessment-evaluation process, the variety of questions according to method of preparation must be increased. The source of the answer in questions should also show diversity, and advanced thinking skills should be supported. A balanced distribution of question levels should be provided in surveys. Pre-service and in-service training should be provided for teachers and teacher candidates in a way that they could provide teaching that will support the development of advanced thinking skills in students and on question preparation techniques. Reasons for insufficiency in teachers in terms of forming and applying questions should be investigated. Studies should be conducted to provide teachers with skills related to asking questions. 